\title{
Dress Syndrome Induced by Antiepileptic Drugs in Hospitals in Bukavu: About Two Cases
}

\author{
Semikenke $S^{1 *}$ and Atadokpédé $F^{2}$ \\ ${ }^{1}$ Service de Dermatologie-Vénérologie, Hôpital Provincial Général de Référence Bukavu /RDC, Republic of the Congo \\ ${ }^{2}$ Faculté des sciences de la santé, Cotonou, Bénin
}

Submission: July 19, 2018; Published: October 24, 2018

*Corresponding author: Semikenke S, Service de Dermatologie-Vénérologie; Hôpital Provincial Général de Référence Bukavu /RDC, Republic of the Congo, Email: stellasemi7@gmail.com

Keywords: Dress Syndrom; Clinical; Antiepileptic drugs; Hospital environment; Bukavu

\section{Introduction}

Dress (Drug Reaction with Eosinophilia and Systemic Symptoms) Syndrome is a rare drug toxidermia that is serious and potentially lethal [1]. It is an acute or subacute idiosyncratic reaction that classically associates a febrile dermatosis, hematologic abnormalities (hypereosinophilia and/or atypical lymphocytosis) as well as multivisceral failure. We are reporting two medical observations of Dress Syndrome induced by antiepileptic drugs.

\section{Patient and Observation}

\section{Observation 1}

It is about a 22-year-old female, who was admitted in dermatology service for a pruritic dermatology. In her recent past health history, she was treated in neurology for seizures following a brain neurocysticercosis. She was on progressive doses of Phenobarbital and Diazepam 2 months prior to the occurrence of skin lesions. The current symptoms started one week prior to our consultation and was marked by a fever of $39.9{ }^{\circ} \mathrm{C}$ followed, three days later, by a sudden appearance of a generalized itching dermatosis. Our physical assessment objectified a fever at 39.3 ${ }^{\circ} \mathrm{C}$, edema of eyelids and lips, maculopapular and erythematous lesions, and cervical adenopathies that were unilateral (left) and centimetric. Biological assessment displayed hyperleukocytosis (WBC $=12400 / \mathrm{mm} 3$ ), hypereosinophilia at $1984 / \mathrm{mm} 3$, and hepatic cytolysis (AST 3 times higher than normal, ALT 5 times higher than normal). Viral serology tests were negative. Chest X-ray and EKG results did not display any abnormalities. REGISCAR score was 5.

All these elements led to a diagnosis of Dress syndrome. Consequently, Phenobarbital was immediately and definitely discontinued. Corticotherapy at a $1 \mathrm{mg} / \mathrm{kg}$ daily dose was launched. The patient evolution was favorable as clinical signs regressed and disappeared within 14 days. Biological assessment tests were normal after 8 weeks. Even 8 months after symptoms have retreated back, there was still no recurrences observed.

\section{Observation 2}

16-year-old boy, who was admitted in consultation for a febrile pruritic dermatosis. In his past health, he beneficiated care in neuropsychiatry for partial seizures that were consequently generalized and presumed to be a probable symptomatic partial epilepsy. He was treated with progressive doses of Carbamazepine one month prior to the occurrence of symptoms.

Symptoms that occurred 8 days before we admitted him were marked by a fever, followed, 2 days later by the appearance of an itching dermatosis.

Physical assessment of the patient found a fever at $39{ }^{\circ} \mathrm{C}$, and maculopapular and erythematous eruptions that were generalized. Biological assessment displayed hyperleukocytosis at $15200 / \mathrm{mm}^{3}$, hypereosinophilia at $1824 / \mathrm{mm}^{3}$, hepatic cytolysis with cholestasis (AST 62 times higher than normal, ALT 56 times higher than normal, Gamma Glutamyl Transferase (GGT) 34 times higher than normal, alkaline phosphatase 7.5 times higher than normal). We could also identify an inflammatory Syndrome with C-reactive protein at $24 \mathrm{mg} / \mathrm{L}$ and a sedimentation rate at $30 \mathrm{~mm} /$ for the first hour. REGISCAR > 5. Diagnosis of Dress Syndrome was retained, and Carbamazepine was discontinued. Corticotherapy at dose of $1 \mathrm{mg} / \mathrm{kg}$ per day was ordered and started. Our followup observed a good progress as testified by a disappearance of clinical and biological signs.

\section{Discussion}

Dress Syndrome is late drug reaction that is rare but serious as it can be life threatening in $10 \%$ of the time [1,2]. This syndrome 
is characterized not only by a long-delayed wait from the time of drug intake up to the appearance of symptoms, but also a prolonged evolution often marked by outbreaks even after the drug in cause has been discontinued. This time in-between is often longer than that of other types of toxidermia. Therefore, it is often subject to delayed diagnosis [2,3]. Medications that are mostly incriminated include aromatic antiepileptic drugs, antibiotics, allopurinol, non-steroid anti-inflammatory drugs and some antiretroviral drugs [2-4]. In our first and second observations, medications that triggered those symptoms were Phenobarbital and Carbamazepine respectively. Time in between drug intake and occurrence of clinical signs were longer for the first case. This could be attributed to the delay in diagnosis and therapy. The most visceral impact is hepatic impairment. It is also the main cause of mortality [4-6]. Cytolysis is also found that in $80 \%$ of the cases. It can be so intense that transaminases are rated 10 to 20 times higher than normal and an anicteric cholestasis with elevation of alkaline phosphatases activity and elevated Gammaglutamyltransferase is often associated. Pure anicteric cholestasis is rarer. Any impairment of hepatic function with decrease in rate of Prothrombin is a sign of severity and can be deadly at times [5]. For both of our patients, hepatic impairment was constant. Furthermore, in one case, an anicteric cholestasis was found. Although the other individual did not display any hepatocellular failure, other liver disturbances were noticed.

\section{Conclusion}

Even though Dress Syndrome is a rare entity, is very serious and it can be life threatening. Our observations illustrate how important an early multidisciplinary intervention is required when faced with this pathology. It is also useful to highlight that drug prescriptions (such as antiepileptic agents) should be based on a strong and reasonable evidence. All these preventive aspects will have an impact on decreasing the frequency of occurrence and improving the prognosis of Dress Syndrome.

\section{References}

1. Debarbieux S, Deroo-berger MC, Grande S, Najioullah F, Kanitakis J, et al. (2006) Syndrome d'hypersensibilité médicamenteuse associé à une primo-infection HHV6. Ann Dermatol Venereol 133(2): 145-147

2. Descamps V, Ben SB, Sassolas B, Avenel AM, Truchetet F, et al. (2010) Prise en charge du Drug Reaction with Eosinophilia and Systemic Symptoms. Ann Dermatol Venereol 137(11): 703-708

3. Descamps V, Ranger-Rogez S (2014) DRESS syndrome. Joint Bone Spine 81(1):15-21

4. Valade S, Toledano C, Tiev K, Gain M, Josselin L, et al. (2009) DRESS syndrome à la phénylbutazone. Rev Med Interne 30(8): 708-10

5. Droz N, Thiebaut M, Terrier B, Bérézné A et al. (2013) Drug Rash with Eosinophilia and Systemic Symptoms (DRESS) syndrome. Rev Med Interne 34(10): 645-8

6. Condat B, Zanditenas D, Collot V, Legoupil N, Cazals-Hatem D, et al. (2006) Une nouvelle cause de cholangite intra et extra-hépatique: le syndrome d'hypersensibilité médicamenteuse ou DRESS. Gastroenterol Clin Biol 30(1): 142-146.

\section{Your next submission with Juniper Publishers} will reach you the below assets

- Quality Editorial service

- Swift Peer Review

- Reprints availability

- E-prints Service

- Manuscript Podcast for convenient understanding

- Global attainment for your research

- Manuscript accessibility in different formats

( Pdf, E-pub, Full Text, Audio)

- Unceasing customer service

Track the below URL for one-step submission

https://juniperpublishers.com/online-submission.php 